\title{
Methodology for planning urban green areas: the case of Mexicali, Baja California, Mexico
}

\author{
C. A. Pena-Salmon \& R. Rojas-Caldelas \\ Faculty of Architecture, University Autonomous of Baja California, \\ Mexico
}

\begin{abstract}
The city of Mexicali has $2.1 \mathrm{~m}^{2}$ public green areas per inhabitant while the national regulation establishes $10 \mathrm{~m}^{2}$ per inhabitant and the World Health Organization establishes $9 \mathrm{~m}^{2}$ per inhabitant, therefore there is an important deficit of public green areas. This article presents a methodological proposal for planning urban green areas and its application in Mexicali. The approach is based on a sustainability perspective in which green areas are not only considered from the social point of view as recreational and sporting facilities, but also as urban elements that can contribute to environmental improvement as well as to reducing the global warming effect by capturing carbon dioxide, which is a greenhouse effect gas. The methodological proposal is composed of five phases: organization, inventory, assessment, strategy and management and the development of six groups of components: the physical-urban, technological, environmental, financial-economical, legal-regulatory, and public participation. The green area inventory and its assessment were done according to a classification in twelve subsystems using a Quickbird satellite image with a $2.6 \mathrm{~m}$ resolution and data was integrated in a geographical information system (Mapinfo). Criterion is presented at the end of this paper for urban green area allocation, according to the social demands of population and the environmental needs as a result of the carbon dioxide emission by the combustion of fuels from automotive vehicles in the city. In addition, several strategies and instruments were defined for the creation, improvement, and preservation of such areas.

Keywords: urban green areas, environmental planning, sustainable cities, green areas indicators.
\end{abstract}




\section{Introduction}

Urban green areas can basically contribute to the sustainable development of cities and improvement of the quality of life of their inhabitants from three perspectives: environmental, social and economic.

From the environmental point of view, urban green areas can modify the microclimatic conditions in open spaces and help to restore physical comfort. They improve air quality, adding oxygen and removing carbon dioxide, which is a greenhouse effect gas, as well reducing soil erosion by the action of wind or water and lastly they constitute themselves the basis of the habitat of fauna and therefore of biodiversity (Nowak and Crane [1]).

From the social point of view, urban green areas constitute spaces where population develop recreational activities and outdoor sports, they support the physical and mental health of the population contributing to stress reduction, and at the same time the improvement of a cities' urban image. Also, it is assumed that they can reinforce the social identity and communitarian sense through population participation in programs, such as urban forestry [2-4].

From the economic point of view, urban green areas can increase the value of land of adjacent properties; they can reduce the consumption and cost of energy in buildings through the control of solar radiation and they also mean an income through urban agriculture (Simpson and McPherson [5], McPherson et al [6]).

In the international context, the examples of programs, plans, congresses, conferences and laws to promote the creation and conservation of urban green areas have been ample, as it is the case of Great Britain (Varese and Bertelli [7]), Austria (Erhart [8]), Spain (Yoldie [9]), The United States (USDA Forest Service [10]), Colombia (Uribe [11]); nevertheless in Mexico and in particular Mexicali city, Baja California, there is a lack of instruments for planning urban green areas.

The city of Mexicali is located in an arid region, northwest of Mexico, with a population of 680,774 inhabitants in 2005 . In the last 25 years urban green areas have been reducing instead of increasing. In 1979, the relation of green area per inhabitant was of $2.5 \mathrm{~m}^{2}$ (SAHOP [12]), whereas in 2005, the relation was of 2.1 $\mathrm{m}^{2} / \mathrm{hab}$ (IMIP [13]), and the national standard for urban public services has settled down $10 \mathrm{~m}^{2}$ of green area per inhabitant (SAHOP [14]).

The aim of this study is to propose a methodology for planning urban green areas for the city of Mexicali that allows an integrated and systematic management of them. The proposal underlines its social importance, environmental contributions to cities and strategies to be implemented for the creation, improvement, and preservation of such areas, to contribute to the wellbeing of the population and city sustainability.

\section{Methodology}

The methodology has considered two broad concepts: the Sustainable Development established by United Nations [15] and the Ecosystem of Guiding Models for Chains of Tjallingii [16]. 
From the United Nations Sustainable Development Agenda, the Implementation Plan for urban green areas has taken into account their contributions to the protection of atmosphere, the improvement of air quality in urban areas and the reduction of emissions of greenhouse effect gases. This study has developed environmental indicators such as surface of green area by typology, tons of emissions of carbon dioxide $\left(\mathrm{CO}_{2}\right)$ and amount of $\mathrm{CO}_{2}$ absorbed by vegetation. From the social perspective priority subjects were transport, recreation and population health and the indicators proposed were surface and density of green areas per inhabitant and neighbourhood, and fuel consumption per inhabitant by use of automotive vehicles.

In order to estimate the carbon dioxide removal through vegetation cover, it was necessary to inventory all kind of surface with vegetation. Urban green areas were considered as all soils made mainly by permeable surfaces and covered for any kind of vegetation as lawns, shrubs and trees, from public or private property and to meet environmental, recreational or productive functions.

Different types of green areas were classified into two main groups (public and private), subdivided into five systems (public services, roads, natural, productive and private) and 12 subsystems related to land use (recreational, sports, education, streets, heritage natural areas, farming, industrial, commercial, tourist, residential, mixed land uses and derelict land) and 50 elements.

It was also important to consider that each one of these green areas types must be located within a hierarchic space scale, from a small residential garden to an urban park in order to identify government participants from federal, state and municipal levels for management actions. According to Tjallingii [17] the space scales that allow solving effective and efficient way environmental problems, are five: building, district, city, region and country.

It must be emphasized; planning of urban green areas is part of a process of urban planning. Therefore, this process should be seen as a methodological guide to elaborate sectoral plans as part of municipal or urban planning.

The methodological proposal was formulated based on diverse processes and reviewed approaches [18-20]. They were integrated under a sequential phases and grouping them by components. The five phases were: organization of planning team, inventory of components, assessment, strategies and finally management plans. The key components were grouped into six types: physicalurban, technological, environmental, financial-economical, legal-regulatory and public participation (Figure 1).

The first phase consists of determining the organizational structure that it is responsible for carrying out the green plan. There are three kinds of participants: the permanent technical team; a temporary team composed by external specialists and; a consultative advice team, integrated by representatives of diverse sectors of the community, they can assess with autonomy the proposals made by the technical team.

The second phase is the inventory of each component: Physical-urban, technological, environmental, financial-economic, legal-regulatory and of public participation. In the case of physical-urban components, it implies to identify, quantify and determine the location of two types of green areas: ones located 
within the urban area and the others at regional level. The latter ones are potential green areas that are not suitable for urban development such as slopes, rivers, flooding zones, landslides, but as well as green areas with landscape attributes; historical, cultural ecological and productive values, which must be preserved.

The third phase is an assessment: One is an assessment by components and the other is an integrated one. From the assessment it is possible to identify existing obstacles as well as opportunities or potentials for planning urban green areas, joining them in a hierarchy in order to define actions and priorities.

The fourth phase is strategy, it includes a long-term plan, where policies and goals are defined and specific programs by component were settled down.

Finally, the fifth phase is management, in which annual action plans and mechanisms of monitoring for its feedback are determined.

\section{Results}

The application of this methodology in Mexicali has begun with an inventory of urban green areas by subsystem which means the present supply; afterwards this supply was contrasted with social and environmental demands of green areas, consequently deficit or surplus was determined and finally strategies and instruments were defined for the creation, improvement, and preservation of such areas.

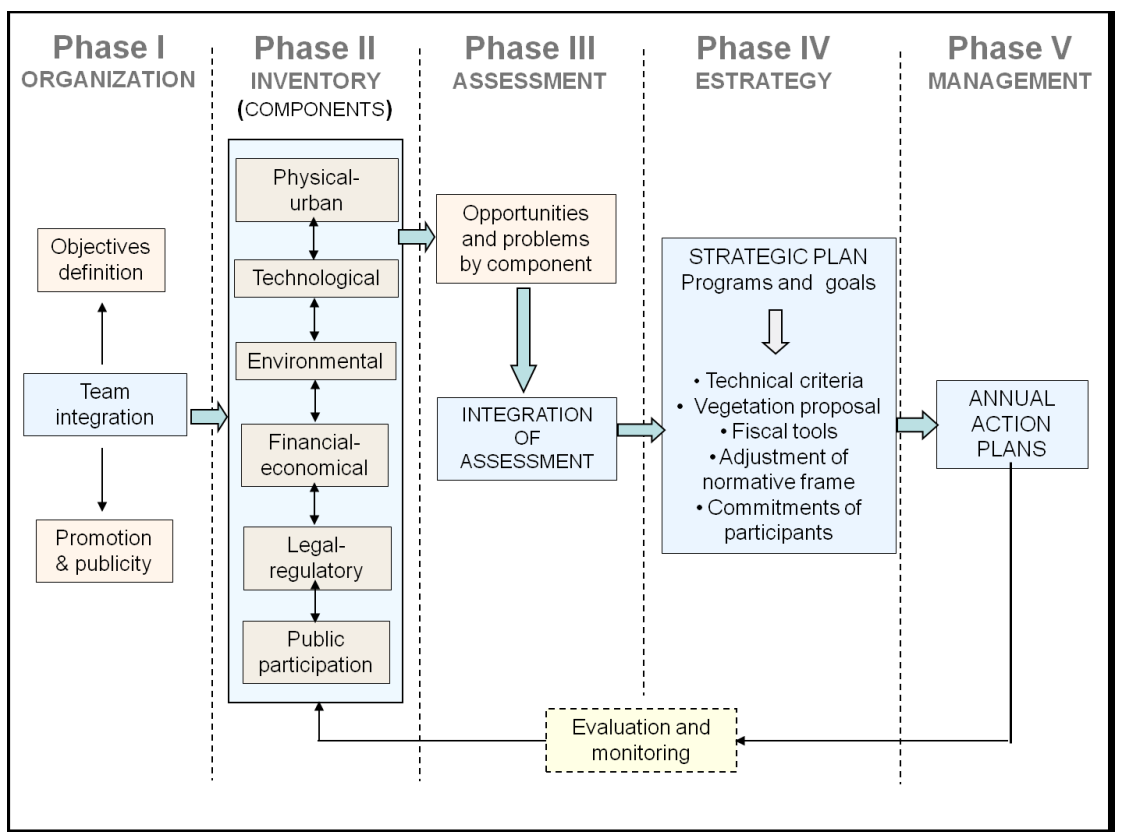

Figure 1: Methodological proposal for planning green areas: phases and components. 


\subsection{Inventory}

The inventory of urban green areas was done using a Quickbird multispectral satellite image with a resolution of $2.6 \mathrm{~m}$ from 2005 and applying Normalized Difference Vegetation Index (NDVI), grouped into two types: the existing green areas and potential green areas. The total cover of existing green areas in urban area was of 2,894.32 ha classified in 12 subsystems (Table 1).

Table 1: $\quad$ Surfaces and percentages of green areas (GA) existing by subsystem and by inhabitants in urban areas.

\begin{tabular}{|c|c|c|c|c|c|}
\hline Type & System & Subsystem & Area $\left(m^{2}\right)$ & $(\%)$ & $m^{2}$ GA/Person \\
\hline \multirow{3}{*}{$\begin{array}{l}\mathbf{P} \\
\mathbf{u} \\
\mathbf{b} \\
\mathbf{I} \\
\mathbf{I} \\
\mathbf{c}\end{array}$} & Public services & $\begin{array}{l}\text { Recreational } \\
\text { Sports } \\
\text { Education }\end{array}$ & $\begin{array}{r}444,624.62 \\
309,414.32 \\
1^{\prime} 666,283.91\end{array}$ & $\begin{array}{l}1.54 \\
1.07 \\
5.76\end{array}$ & $\begin{array}{l}0.65 \\
0.45 \\
2.45\end{array}$ \\
\hline & Roads Green Areas & Streets & $2^{\prime} 875,055.53$ & 9.93 & 4.22 \\
\hline & Heritage Natural Areas & Natural and adapted & $864,159.27$ & 2.99 & 1.27 \\
\hline \multirow{7}{*}{$\begin{array}{l}\mathbf{P} \\
\mathbf{r} \\
\text { I } \\
\mathbf{v} \\
\mathbf{a} \\
\mathrm{t} \\
\mathrm{e}\end{array}$} & \multirow{4}{*}{$\begin{array}{l}\text { Productive Green } \\
\text { Areas }\end{array}$} & Farming & $5^{\prime} 439,174.18$ & 18.79 & $7.99^{*}$ \\
\hline & & Industrial & $513,198.48$ & 1.77 & 0.75 \\
\hline & & Commercial & $455,694.79$ & 1.57 & 0.67 \\
\hline & & Tourist & $493,517.70$ & 1.71 & 0.72 \\
\hline & \multirow{3}{*}{ Private Green Areas } & Residential & $6^{\prime} 379,090.22$ & 22.04 & 9.37 \\
\hline & & Mixed land uses & 805.651 .87 & 2.78 & 1.18 \\
\hline & & Derelictland & $8^{\prime} 697,346.82$ & 30.05 & $12.78^{*}$ \\
\hline Total & & & $28^{\prime} 943,211.71$ & $100 \%$ & $45.52 \mathrm{~m}^{2}$ \\
\hline
\end{tabular}

From the total subsystems, those of smaller percentage are public green areas: recreational $(1.54 \%)$ and sports $(1.07 \%)$, while those of greater percentage are the private green areas like residential ones $(22.04 \%)$. The subsystems of farming and derelict land should not be considered, since these land uses will be incorporated to urban development in the middle or long term, therefore the existing network of urban green areas are 1480.67 ha, which represent the $7.10 \%$ from the total of urban area $(20,848.39 \mathrm{ha})$.

Regards to potential green areas, were identified 12,160 ha, related to agricultural lands surrounding the city, and there were considered lands of high productivity, level 1.

Different types of green areas were located according to a hierarchy scales, from building to regional (Figure 2).

\subsection{Assessment}

Regards to social needs of green areas (recreational and sports facilities) it was determined a demand of $157.61 \mathrm{ha}$, considering the criterion of $2.32 \mathrm{~m}^{2}$ of green area per inhabitant (SEDESOL [21]) and the supply of 75.40 ha of existing green areas and 86.41 ha of potential green areas, adding a total of 161.81 ha; consequently if the potential green areas are developed then social needs will be covered. 


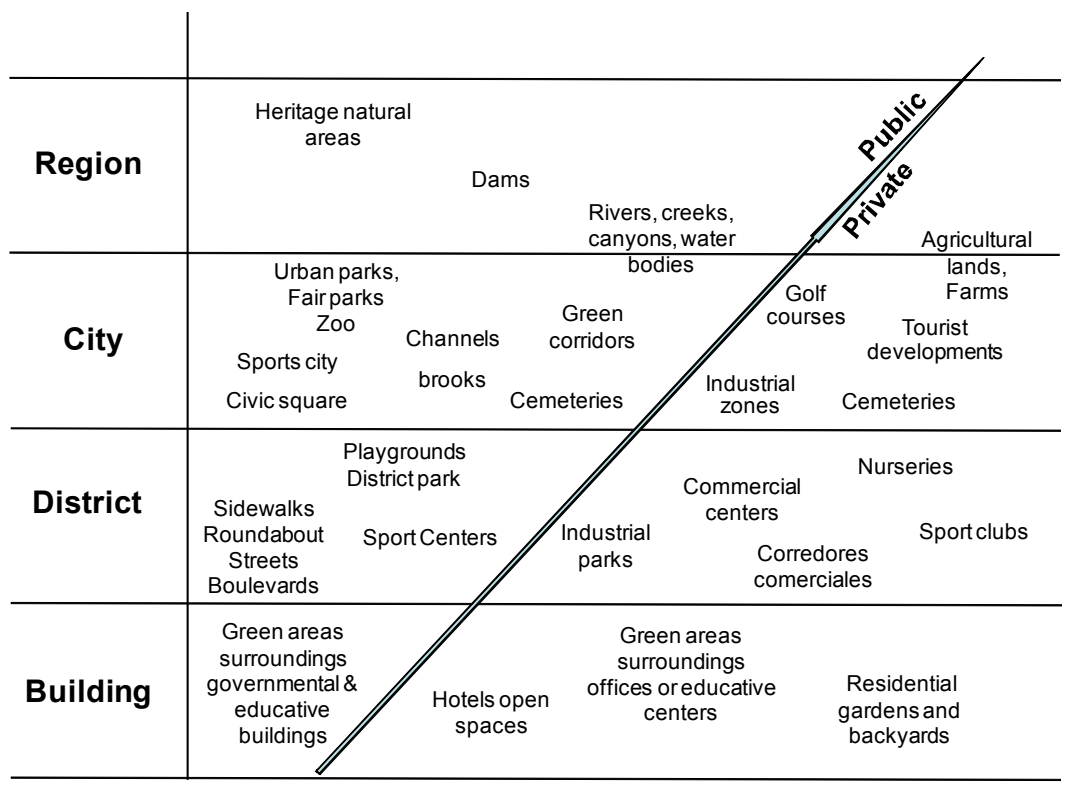

Figure 2: $\quad$ Types of green areas by hierarchy scales.

Related to environmental needs, firstly it was estimated the annual volume of $\mathrm{CO}_{2}$ emissions produced by gasoline and diesel consumption. The annual gasoline consumption of 278,414 vehicles was $808,380 \mathrm{~m}^{3}$ (SEMARNAT [22]) that produced $1,835,022$ ton of $\mathrm{CO}_{2}$, considering an emission factor to atmosphere of 2.27 ton $\mathrm{CO}_{2}$ by $\mathrm{m}^{3}$ and the annual diesel consumption of 34,638 trucks was $253,598 \mathrm{~m}^{3}$, considering an emission factor of 2.81 ton $\mathrm{CO}_{2}$ by $\mathrm{m}^{3}$ (McPherson and Simpson [23]), that produced 712,610 ton of $\mathrm{CO}_{2}$, so the total $\mathrm{CO}_{2}$ annual production was $2,547,632$ ton.

Therefore, the vegetation cover necessary to remove $\mathrm{CO}_{2}$ produced in a year was estimated in 12,017.13 ha of green area, considering an average of $\mathrm{CO}_{2}$ removal of 212 ton/ha/year, USDA [24]. Considering the potential green areas supply $(12,160 \mathrm{ha})$ they must be preserved, in order to cover the environmental needs.

\subsection{Strategy}

In this phase policies and programs were set up in three main directions: 1. to create new green areas through reserving great surfaces to develop in the middle and long term; 2. to protect existing green areas; and 3. to improve or rehabilitate deteriorated green areas that require certain actions for their recovery (Figure 3).

The strategy includes policies, programs and instruments defined through the elaboration of a green plan of great vision with goals to short, middle and long term, in which priorities and strategies were set up to increase and preserve these areas, regulatory instruments to give legal basis and financial resources were identified as well as ways of community participation. 


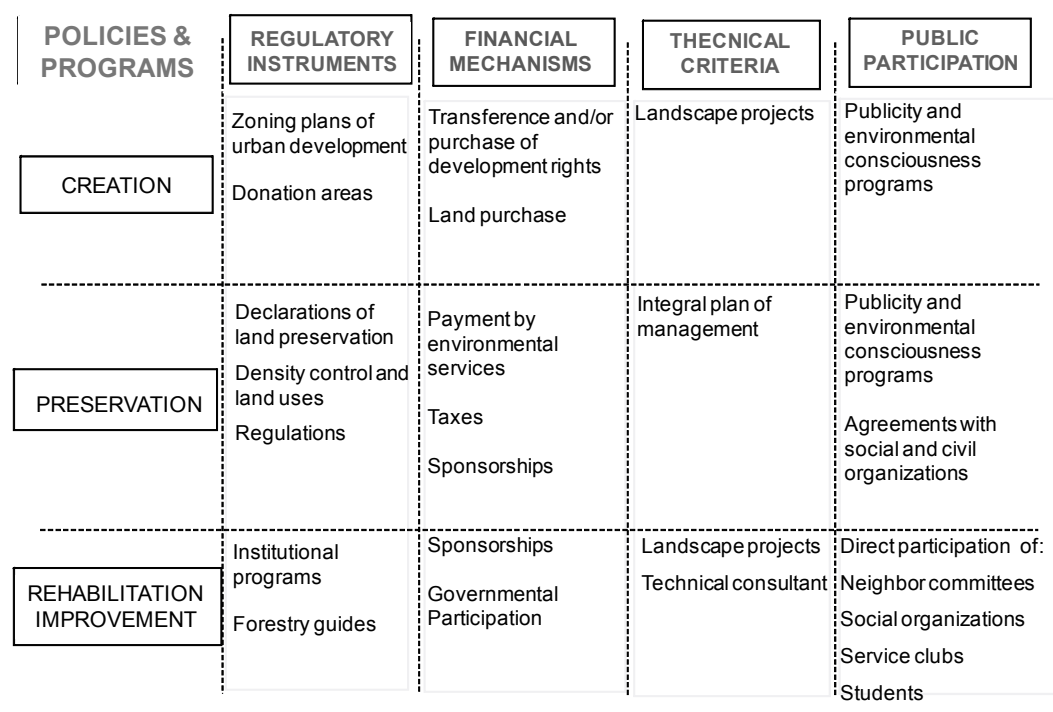

Figure 3: Policies, programs and instruments for the creation, conservation and rehabilitation of urban green areas.

\section{Conclusions}

In the inventory of green areas one of the great advantages of using multispectral images was the accurate identification of vegetation cover, and applying vegetation index NDVI that registers photosynthetic activity of plants was to avoid over-estimation of vegetation cover caused by tree shades when making photo interpretation

It is also important to emphasize that in the case of the assessment of environmental needs of green areas, in relation to carbon dioxide emissions by consumption of fuels as well as absorption of $\mathrm{CO}_{2}$ by diverse types of vegetation, the criteria and indexes are diverse, and should be considered as estimations, but they can be relevant considerations for decision making.

Nevertheless, the incorporation of environmental components is a contribution in the methodology because the criterion of allocation of urban green areas has been mainly done considering only the social function of green areas as recreational and sport facilities, but not considering its environmental services like elements that can help to remove $\mathrm{CO}_{2}$, to improve air quality and to contribute to reduce greenhouse effect.

Talking about strategies, it is important to mention that general proposals or unique forestation programs for the whole city are inoperative, because each green area subsystem has its own characteristics, therefore programs for creation, conservation and improvement of green areas will have to be formulated and adapted for each particular subsystem.

Urban green areas do not create by themselves sustainability but they can contribute to sustainable development in several ways: covering social demands 
of population as recreational and sports spaces, improving urban image, improving air quality, removing carbon dioxide emissions, reducing electrical power consumptions and adding value to properties; in sum, contributing to well being of population.

Finally, urban green areas play an important role in cities development, so they must be revalue within urban planning process and municipal authorities must take leadership and recognize them like essential spaces in cities by their contribution to population quality of life; they should be considered as an investment in long term and not as a cost in the short one. A better understanding of urban green areas and an environmental consciousness among population and authorities is needed to preserve them, because green areas are somehow of all of us, everybody enjoy them from one or another way their vital benefits.

\section{References}

[1] Nowak, D.J., Crane D.E., Carbon storage and sequestration by urban tress in the USA. Environmental Pollution 116 (2002) pp.381-389, 2002.

[2] McPherson, E.G. and C. Johnson, A Community Forestry Planning Process: Case Study of Citizen Participation. Landscape and Urban Planning, 15, pp.185-194, 1988.

[3] Palomo, P.S. La Planificación Verde en las Ciudades. Editorial Gustavo Gili, Barcelona, España, 2003.

[4] Tzoulas, K., Korpela, K., Venn, S., Pelkonen, V.Y., Kazmierczak, A., Niemela, J., James, P. Promoting ecosystem and human health in urban areas using Green infrastructure: a literature review. Landscape and Urban Planning 81 (3), pp. 167-178, 2007.

[5] Simpson, J.R.\& McPherson E.G., Tree planting to optimize energy and $\mathrm{CO}_{2}$ benefits. Center for Urban Forest Research. PSW Research Station USDA Forest Service Online. http://wcufre.ucdavis.edu/research/ studies_detail_summary

[6] McPherson, E.G.; Scott, K.I; Simpson, JR., Estimating cost effectiveness of residential yard trees for improving air quality in Sacramento, California using existing models. Atmospheric Environment, 32(1), pp. 75-84,1998.

[7] Varese, G. B, Ugo Bertelli, Development of Urban Green Spaces to Improve the Quality of Life in Cities and Urban Regions EVK4-CT-200000022. Planning Criteria. Website www.planning.odpm.gov.uk

[8] Erhart, E., The Greenstructure of Vienna in Green Structure and Urban Planning-PROGRESS REPORT- 2002, Bernard Duhem -Chairman. Online. http://www.map21ltd.com/COSTC11/Vienna.htm

[9] Yoldie, E.L., Plan Verde para una Ciudad Patrimonio de la Humanidad, Segovia (España). Online. http://habitat.aq.upm.es/bpes/onu98/bp446.html

[10] USDA Forest Service, General Technical Report PSW'GTR 171. McPherson, E.G.; Simpson J. Carbon dioxide reduction through urban forestry: Guidelines for professional and volunteer tree planters. Pacific Southwest Research Station Forest Service, U.S. Department of Agriculture; 237p. Online http://www.psw.fs.fed.us/techpub.html 
[11] Uribe, B.E., Enverdecimiento urbano en Colombia, en Krishnamurthy L. y J. Rene Nascimento (eds.) (Chapter IX). Áreas Verdes Urbanas en Latinoamérica y el Caribe. Centro de Agroforestería para el Desarrollo Sostenible. Universidad Autónoma Chapingo. México, pp. 253-304, 1998.

[12] SAHOP, Ecoplan Baja California 4a. Fase- Normas y Políticas de forestación y áreas verdes para Mexicali, Tijuana y Ensenada. México, 1979.

[13] IMIP (Instituto Municipal de Investigación y Planeación Urbana de Mexicali) Programa de Desarrollo Urbano de Centro de Población de Mexicali B.C. 2025, Versión abreviada para consulta, November 03 2005, [versión electrónica, 2005.

[14] SAHOP, Manual para la elaboración de programas de desarrollo urbano de centros de población. México, 1981.

[15] United Nations, Division for Sustainable Development. Indicators of Sustainable Development: Guidelines and Methodologies April, New York. Website, www.un.org/esa/sustdev/isd.itm

[16] Tjallinglii S., ECOPOLIS, Strategies for Ecologically Sound Urban development. Netherlands. Backhuys Publishers, 1995.

[17] Ibidem

[18] Palomo, P.S., La Planificación Verde en las Ciudades. Editorial Gustavo Gili, Barcelona, España, 2003.

[19] Krishnamurthy, L. y J. Rente Nascimento (eds), Áreas Verdes Urbanas en Latinoamérica y el Caribe. Centro de Agroforestería para el Desarrollo Sostenible. Universidad Autónoma Chapingo. México (1998)

[20] Pérez, M., Análisis de una Metodología para el inventario de Espacios verdes en una Ciudad Intermedia. Instituto de Planeamiento Urbano y Regional (I.P.U.R.) - Facultad de Arquitectura y Urbanismo - UNNE. Argentina. Online. http://www.unne.edu.ar/cyt/2001/7-tecnologicas/t012.pdf

[21] SEDESOL, Sistema Normativo de Equipamiento Urbano: Manuales Técnicos. Subsecretaría de Desarrollo Urbano y Vivienda, Dirección General de Infraestructura y Equipamiento. México. [Versión electrónica], 2001.

[22] SEMARNAT, Gobierno del Estado de Baja California, XVI Ayuntamiento de Mexicali. Programa para mejorar la calidad del aire de Mexicali 20002005. 1 $1^{\mathrm{a}}$. Edición. México.1999.

[23] McPherson, E.G. and J. R. Simpson, Carbon Dioxide Reduction Through Urban Forestry: Guidelines for Professional and Volunteer Tree Planters. United States Department of Agriculture, Forest Service, Pacific Southwest Research Station, General Technical Report PSW-GTR-171. Online. www.fs.fed.us/psw/publications/documents/gtr-171/gtr-171-cover.pdf

[24] USDA National Agroforestry Center. Working trees for carbon cycle balance. Agroforestry: using trees and shrubs to produce social, economic and conservation benefits. Online. http://www.unl.edu/nac/pubs.html\#other 